\title{
The Charing Cross: Unfolding a Genius Loci in Lahore, Pakistan.
}

\author{
Hafsa Imtiaz, Mehreen Mustafa \\ National College of Arts: 4-Shahra-e-Quaid-e-Azam, Lahore, Pakistan \\ Institute for Art and Culture: 7.5km Thokar Niaz Baig, Adjacent Govt. Technical College, \\ Main Raiwind Road, Lahore \\ hafsaimtiaz@gmail.com \\ mustafa.mehreen@gmail.com
}

\begin{abstract}
The Charing Cross, Lahore may be ranked as more than simply the junction of roads. It is a memorial representing architectural, social and cultural history of Lahore. Imprints of Colonial, post-colonial and modern era can be traced if the evolution of architectural space and elements of The Charing Cross, Lahore are closely examined. The multi-faceted space of The Charing Cross, Lahore is understood if a temporal cross-section of the square is cut and critically analyzed. Designed and built during the British (colonial) times, the square has, from the beginning, marked its genius through its ideal location and spatial quality. From being a centrally located square with carefully marked monuments and buildings to a democratic and recently politically charged demonstration space, the square in Lahore has changed with time but retains its Genius Loci through its form and events. In addition, a number of attempts made for shifting the location and position of the monument within the confined periphery of Chowk demonstrates how the monument has been treated by the ruling elite and people of Lahore at different times. The Charing Cross, Lahore is seen as a palimpsest with each layer of time and space reinforcing the genius Loci of the square within the city of Lahore. The paper analyzes the juxtaposition of time and space boundaries that have contributed in making the historic Chowk of The Charing Cross Lahore; a genius Loci.

The paper begins with an introduction to the space with a brief background to its history and evolution. It then moves towards introducing the theory and the methodology through which the paper signifies the square in relation to the events. Supported by the critical analysis of the historical (physical and social) evolution of the square, the paper establishes the significance of The Charing Cross and its genius Loci.
\end{abstract}

Keywords: The Charing Cross, Place making, Genius Loci, Public space, event, time.

\section{Background:}

Uniqueness of any place is established by its versatility to withstand the pressures of time and change as the need arises, without losing neither its essence nor its soul. Lahore is an old city and it has been tested repeatedly by time for its endurance and 
flexibility. It is important to note that the history of Lahore has seen many invasions and it may not matter who won in the end. The important thing was that with each attack, the city survived and to some extent even thrived. Two important eras exist which have significantly shaped the urban fabric of Lahore and have left a legacy and itinerary for the city to follow. The two important eras are the Mughal era $\left(15^{\text {th }}\right.$ century to $18^{\text {th }}$ Century) and the British ( $18^{\text {th }}$ Century to $20^{\text {th }}$ Century) where the Mughals have left their mark in the form of the walled city in Lahore. The British came with a different understanding and approach to the city. The city of Lahore has always been known as the city of Gardens and building up on this reputation the British chose to develop and extend the city as a combination of their own aesthetics and the existing essence of the city. The result was an amalgamation of contrasting urban forms co-existing on the same plane.

After the battle of Gujrat in 1846, Lahore was made a part of the British Raj and the Cantonment was moved to the southeast of the city just past the Mian Mir village. A metallic road, known as the Mall was constructed in 1860 to link the walled city and the growing city to the Cantonment and the canal was further developed as one of the defenses, amongst other things, for the Cantonment. The Mall was divided to two sections; the lower mall and the upper Mall. Most of the administrative buildings were strategically placed on the Mall to display the power of the rulers. Among the planning and construction of eclectic style buildings, the British brought with them a new form of urban space known as the 'Square'. In Pakistan, the term 'square' is synonymous with 'chowk' and is usually applied to a central area formed around the intersection of three or more streets comprised of some open area filled with traffic islands and other traffic calming features (Naz and Ashraf, 2008). The Charing Cross, Lahore is an important square and landmark in Lahore that has seen many a turbulent as well as historic moments that mark the square as an integral space within the fabric of the city. While it takes its name from the famous Charing Cross of London, the square does not share many similarities with its predecessor.

\section{Theoretical}

framework:

Since the ancient times, the genius Loci, or 'spirit of place', has been recognized as the concrete reality Man has experiences in his daily life. The origin of the word loci is locus (1523-34) meaning a place ${ }^{1}$. However, the word has been used in different ways in biology and mathematics referring to the set of all points, lines, or surfaces that satisfy a given requirement and the chromosomal position of a gene as determined by its linear order relative to the other genes on that chromosome respectively.

In classical Roman theology, Genius Loci is referred to as the "protective spirit of a place" and was represented with the help of scared symbols inside / outside a building. (Brisch, 2008). In 1966, Italian architect Aldo Rossi investigated the classical myth of Genius Loci and drew its relevance to architecture and urban design through his remarkable book "The Architecture of the City". Rossi suggested that Genius is something much more than simply the protective spirit of a place. He proposed that it is a set of unique and significant relationships between places, material dimensions of its

\footnotetext{
${ }^{1}$ Dictionary.com. (2018). Dictionary.com. Dictionary.com. https://www.dictionary.com/Accessed
} September 5 . 
architecture and the activities, which are unfolding in its domain. According to Rossi, the genius can reside,

In the single artifact, in its material, the succession of events that unfolds around it, and the minds of its makers; but also in the place that determines it-both in a physical sense and above all in the sense of the choice of this place and the indivisible unity that is established between it and the work.

(Rossi,1966;113)

Another interesting aspect of Rossi's thesis was that he highlighted the significance of 'urban artifacts' such as monuments as a tool to study urban history. According to Rossi, these moments are the true keepers of our collective memory i.e. events and time that has been witnessed by an era in past and therefore, by understanding the genius Loci of these urban artefacts, we can understand the historical evolution of the cities. In reference to the Charing Cross, Lahore, the marble pavilion and the buildings designed around the Cross act as urban artifacts and mark the moments, events and history to immortalize the Square. Moreover, the square itself, due to its location and relation to the city, signifies as an urban artifact. With this founding, it becomes imperative to understand and study the history of Lahore and see how these urban artifacts contributed in the making of the Cross a genius Loci.

Another important work, which attempts to understand and develop a link between man and his environment, is Christian Norberg Schulz. In 'Towards a phenomenology of Architecture' (1996), Schulz uses an existential approach to understanding architecture, idea of place and how Man perceives the spaces around him. Schulz makes two distinctions; between space and place or rather the making of a place from a space and that of defining genius Loci. As Schulz states:

"The man-made environment where he lives is not a mere practical tool or the result of arbitrary happenings; it has structure and embodies meanings. These meanings and structures are reflections of man's understandings of the natural environment and his existential situation in general. The architecture of early civilizations may therefore be interpreted as a concretization of the understanding of nature, described above in terms of things, order, character, light and time.

(Schulz, 1996;50)

Architecture means to visualize the Genius Loci, and the task of architecture is to create meaningful places, whereby it helps Man to dwell. If cities are understood having something to make possible the urban dwelling, then the Genius Loci has to have the properties of a place and events marking the significance of that particular space in the city. The Genius Loci thus denotes what a thing is, or what it 'wants to be' (Schulz, 1996). The journey of a space into being a place and then its transformation to Genius Loci is important, as the place is a space with distinct character; the transcendence of place to its highest possible and meaningful place is that of genius Loci. But the question 
that constantly arises is what and how a place recognizes and demonstrates its genius. Is there one particular incident in universe which marks a certain locations into Loci or particular events or may be both? The analysis of the paper, with the help of the Charing Cross, concludes that time and space boundaries always juxtapose in order to facilities the genius of a place. Time and events are both equally important characteristics, which lifts the status of a space into a Genius Loci.

\section{Methodology:}

The paper investigates the making of the space of the Charing Cross, Lahore and recognizes and marks the events that helped shape the genius of the Cross. Adding the layers of time into it, The Charing Cross, Lahore becomes an important study to comprehend the evolution of space; with the force of each historic event pushing towards the culmination of space into genius Loci. 'In the case of The Charing Cross, Lahore, it is interesting to study not only the final evolution of the Cross into genius loci but the process through which it achieved the status. Following methodology is adopted to support and establish that The Charing Cross, Lahore has a distinct Genius Loci.

- Documentary research: The Charing Cross of Lahore and the socio- political history of Lahore city.

- Study of data collected through interview, newspapers and photographs.

- Study of archival material available on the subject. For example, maps \& photographs showcasing the progression of the urban morphology of the square or draft of resolutions and speeches delivered in or around the square.

- Analyzing the available data in reference to the historical evolution of The Charing cross at two levels. (Fig 1)

- Urban morphology of the square and its context

- Historical analysis of movements augmenting in and around the square

- Identification and analysis of: (Fig 2)

- Significant events taken place at The Charing Cross, Lahore, which have altered the course of history

- Significant spatial amendments proposed or materialized in the square which have transformed or influenced the socio- political scenario of Lahore city.

It is also important to note here that while a lot has been written on the idea of Genius Loci, very little has been written on the social and physical evolution of the Charing Cross, Lahore. In addition, no noticeable attempt has been made to analyze the idea of Genius Loci and establishes its relevance in Asia. 


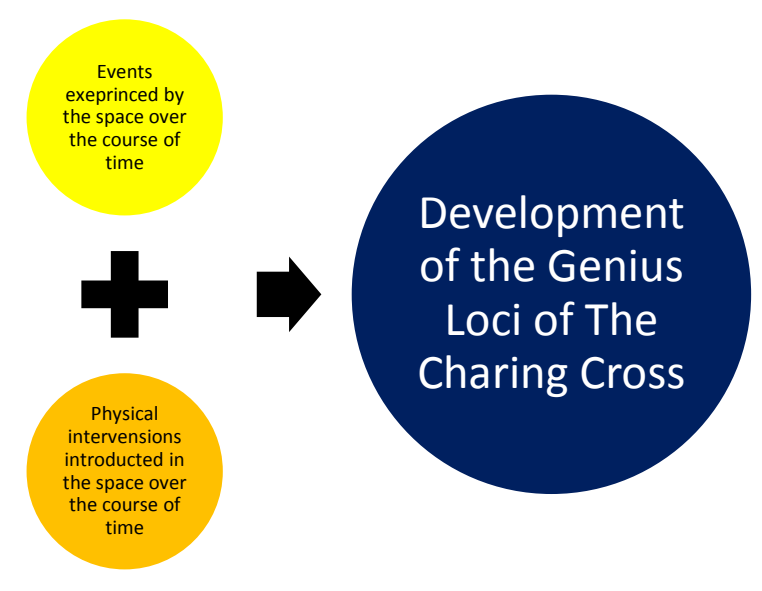

Fig. 1: Analysis of data available on The Charing Cross, Lahore at two levels to support the argument: The Charing Cross, Lahore is a Genius Loci Source: Author

An investigation into the built fabric and urban transformation of The Charing Cross, Lahore helps understand the relationship that the Genius of The Charing Cross, Lahore has with the evolution of space unfolding in its context. The paper investigates the genius of The Charing Cross, Lahore at two levels; in the first stage the physical evolution of the urban form of the square is studied through cartographic maps and photographs. This helps to understand the change in the urban morphology of the square especially in the colonial and post-colonial era. In the second stage, the paper analyzes, marks and maps the events shaping the genius of the square through event-space diagrams and photographs.

\section{Tracing the urban morphology of The Charring Cross, Lahore:}

Time is an elusive entity, which cannot be seen, felt or touched but can be measured through the painful display of human expression. The many layers of manmade and natural space, reflect time in its purest form and reading the change in space in reality displays the length and effects of time. In this regard, spaces evolve into places and cities are the amalgamations of these place. As a result, then cities, in reference to the significant places, are the true keepers of time. The Charing Cross, Lahore in a way is thus a palimpsest of time the City of Lahore has witnessed.

The Charing Cross, Lahore was planned and carved on the urban fabric of Lahore as a rough scalene shape triangular junction at the intersection of Queens', Montgomery and Mall road (Survey Plan 1913), free from the formalities of architectural characterness. A white marble pavilion harboring bronze statue of Queen Victoria, vernacular in its architectural language and designed by Bhai Ram Singh, was later employed at the base of scalene shape triangular junction. Planned in the elite area of Donald Town and 'The Charing Cross Scheme' with an enclosed garden, it is interesting to note that initially the Cross was not signified by any name but by the Statue of the Queen Victoria, and that is the first event, which vitalizes the genius of the Cross. 


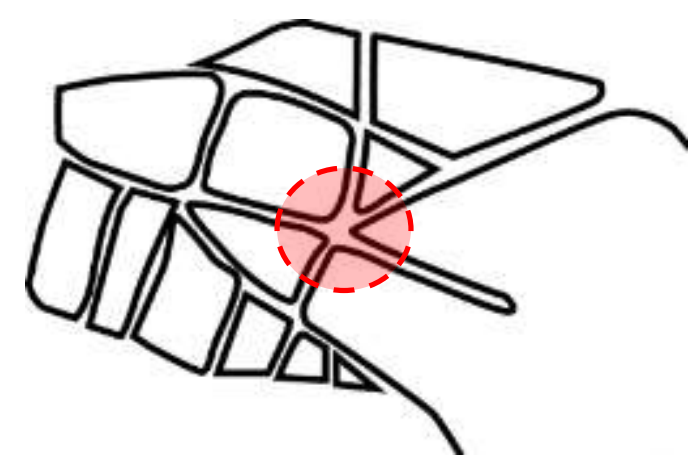

Fig. 2: The Charing Cross, Lahore 1893 Source: Author

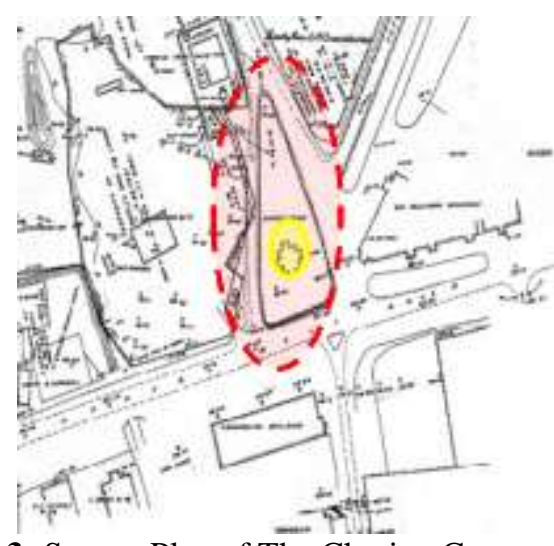

Fig. 3: Survey Plan of The Charing Cross , Lahore ground (1913)

Source: Author \& Communication \& Works Dept. Govt. of Punjab, Lahore

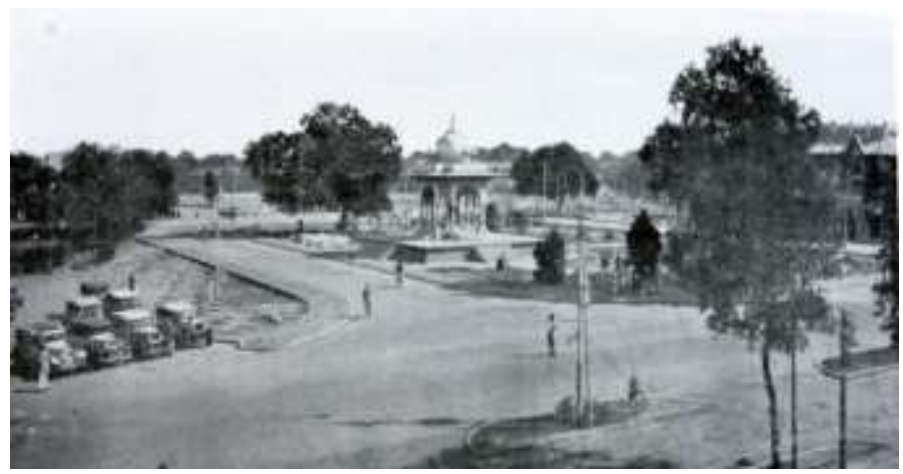

Fig. 4: White Marble Pavilion installed in The Charing Cross, Lahore Source: Aijazuddin F.S.; Lahore Recollected: An Album

The construction of Shahdin Manzil and the Freemasons Hall in 1917 by Basil M. Sullivan marks as the first attempt to envision The Charing Cross, Lahore as an enclosed space. The semi-circular flanking buildings right across from the marble pavilion strategically balances the space making. This is the first planned urban square in the city of Lahore of that scale. Sullivan conceived the buildings as identical in design but asymmetrical on the map. This brought order to the space and its context. 


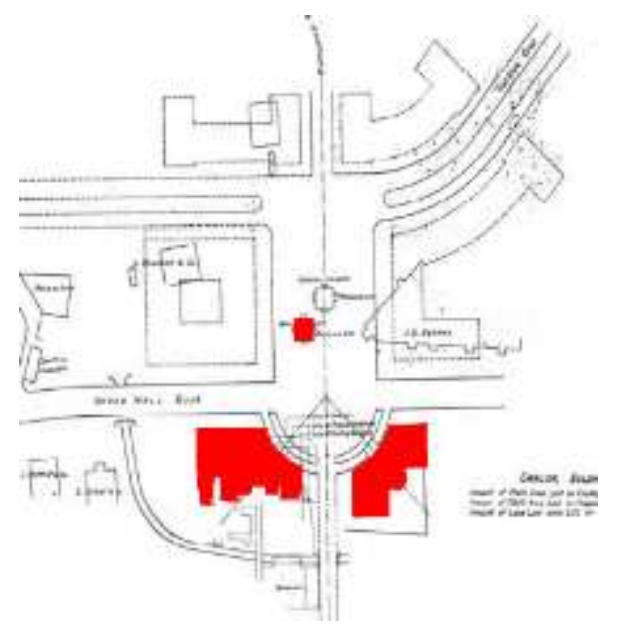

Fig. 5: Improvement Plan of The Charing Cross, Lahore by Basil M. Sullivan (1914) Source: Author \& Communication \& Works Dept. Govt. of Punjab, Lahore Map: Author

Shahdin Manzil has been the witness to the many changes proposed and executed on The Charing Cross, Lahore. Named after the first Judge Mian Shah Din, the building has survived for more than 100 years. Standing silently in one corner of the Charing Cross, the building is a reminder of the glorious days of the past. At that time, it was designed to house the elites of the British society. Following many years of neglect, the building was heavily damaged and had to go through some major renovation. This resulted in the restoration of the façade and rejuvenation of the interior of the space. The building presently houses a Bank.

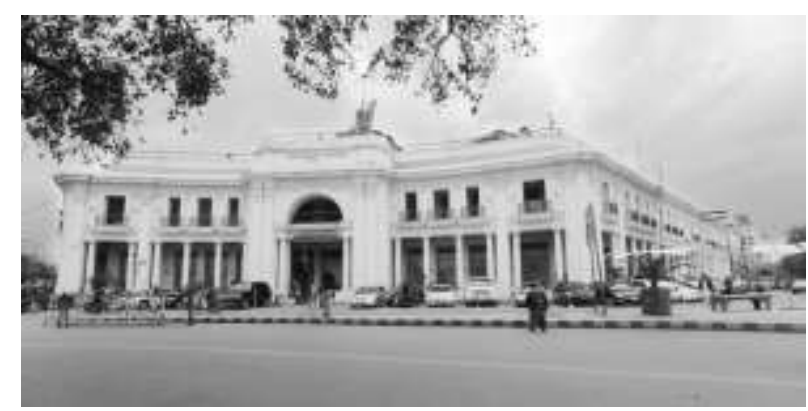

Fig. 6: Shahdin Manzil

Source: http://tns.thenews.com.pk

Built on the same lines as that of Shahdin Manzil the Masonic Lodge has neoclassical architectural style and has the same height, design and finishes. The two buildings together form a sort of an enclosure to The Charing Cross, Lahore bringing symmetry and balance to the square. The renovation in 2005 to the Shahdin Manzil added a metallic dome, which gives it a different look than its partner on the opposite corner. 
The two impressive structures situated on the south of The Charing Cross, Lahore have provided the backdrop to many events throughout history. They have witnessed the colonial times to the resistance and fight for freedom to the more recent post-colonial political tensions and rallies.

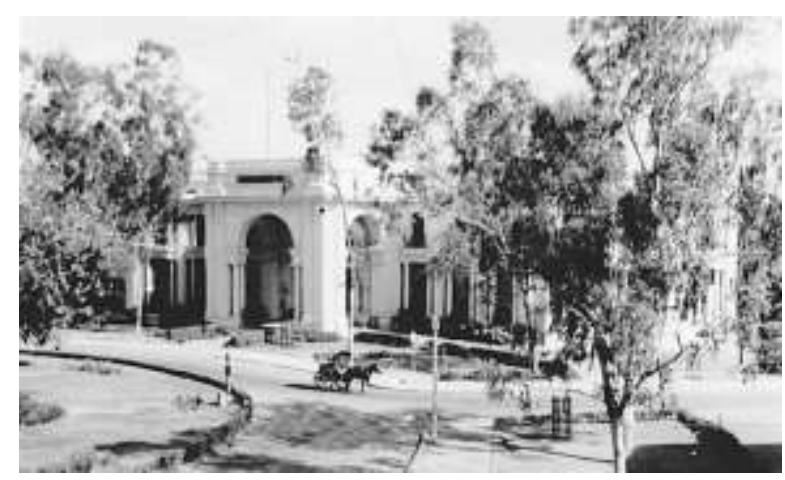

Fig. 7: Masonic Lodge Source: http://lahore.city-history.com

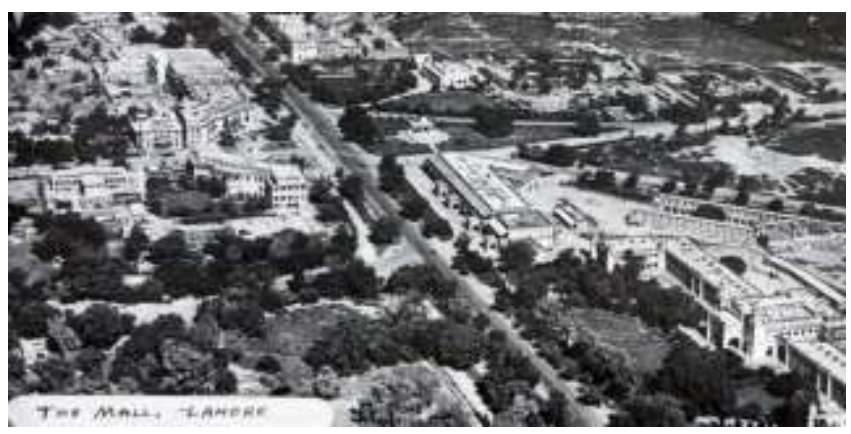

Fig. 8: The Charing Cross, Lahore at the time of construction of Masonic Lodge and Shah Din Building (1920)

Source: Aijazuddin F.S.; Lahore Recollected: An Album

The Charing Cross started taking its present form when the building for Punjab Assembly was approved to be built opposite from the marble pavilion (facing the semicircular buildings of Masonic hall and Shahdin Manzil). With the design of the assembly hall, the physical fabric of The Charing Cross, Lahore would change dramatically, adding an air of formality and order. Built in 1935-1938, the complex covers an area of 112 Kanal (50,4000 sqft) and was planned on the same principles of the neo-classical style. 
Fig. 9: Punjab

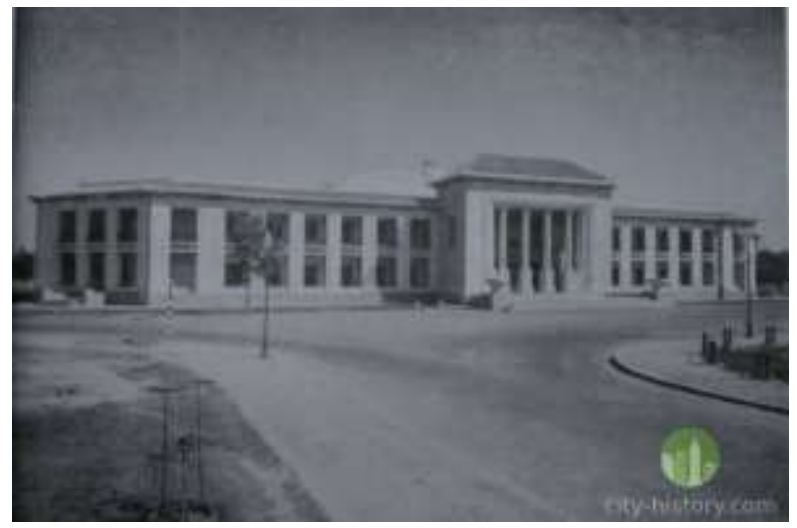

Source: Lahore City History

Assembly

Post-independence saw massive scale development in the city of Lahore. Being the central hub for administrative and political buildings, The Charing Cross, Lahore remained a prime location for further additions of structures. In this regard, a huge complex of Alfalah building and WAPDA house was conceived to house the offices of Water and Power Development Authority. The building designed by American architect Edward Durrel Stone is a massive structure of 9 story including 2 basements. The structure makes an attempt at blending in with the existing language of the Cross through its curved form yet it's massive scale, where it becomes an important landmark, turning out to be an imposing structure, over powering the rest of the built fabric of the Cross.

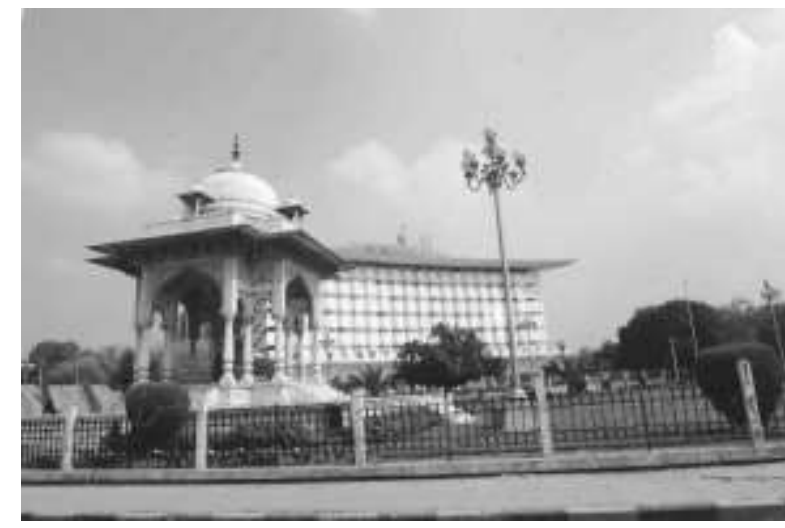

Fig. 10: WAPDA House

Source: The Dawn National Weekend, Jan 2015

With the addition of Summit Minar in 1977, The Charing Cross, Lahore realized its present form. The Minar and complex was designed to commemorate the historic event of second Islamic summit held in the Punjab assembly. The map on the opposite side shows the original marble pavilion, the two semi-circular buildings, the punjab assembly, WAPDA house, alfalah house and finally the addition of Summit Minar in the central space. It is interesting to note the representation of almost 70 years of history through the mix of these buildings. 


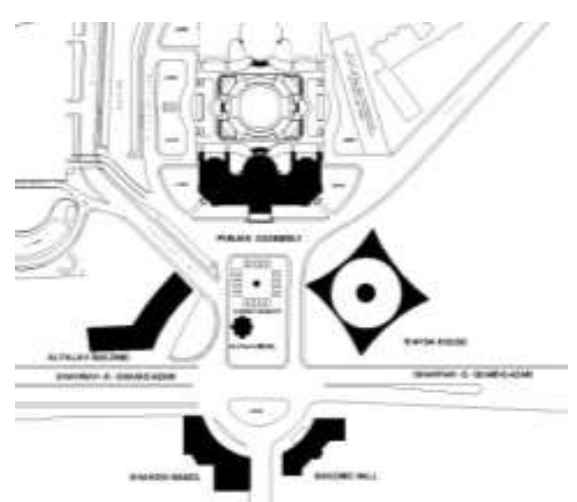

Fig. 11: Existing plan of The Charing Cross, Lahore Source: Author \& Communication \& Works Dept. Govt. of Punjab, Lahore

\section{Unfolding the Layers of Events at The Charing Cross, Lahore:}

A space needs two distinct qualities to achieve the status of place; orientation and identification (Schulz, 1996) The identification primarily refers to the physical space, where each built structure adds to the memory of the user and can provide the means to recognize the genius of the place. The other is the ability of the user to orient within the place and to the place within the city. Orientation of and to the place is integral to the realization of its genius as it reflects the capacity of the place to retain itself in the memory of the user through its events. Events connect the tangible to the intangible; or in this case the built fabric of The Charing Cross, Lahore to its genius. It is through these events; built layer by layer over a period of time that the genius of the place matures. Event has the innate propensity to sketch a mortal or immortal mark on the face of time and space by the very nature of its occurrence, significance and relevance. If of profound character and impact, events can shape and even re-craft the social and cultural spirit of a place. Such events are triggered either by incidents that have jolted the consciousness of people or by a cause which felt too important to be left on the mercy of time. However, often, there are places, which by the virtue of their spirit and culture (tangible and intangible) emerge to be the only appropriate place for the commencement of events advocating communal interest and cause.

Foucault perceives space as an active power discourse, which may be used to control and discipline society (Ghias \& Abbas, 2017). However, interestingly the power discourse of a space, especially a public space, can also be exercised by the society for simply refusing or challenging the status quo. Such episode of power display be it by the people or the authorities, exalt a "space" into the prestige of "place". The power discourse of The Charing Cross, Lahore began to initiate right with the ceremonial event in which the bronze statue of Queen Victoria was displayed in the marble Pavilion. The ceremony acting as a significant event in itself elevated the status of The Charing Cross, Lahore from simply an intersection to a politically charged urban setting. The event of the employment of Queen's statue as physical and symbolic representation of British power was the first of its nature to have contributed in making the 'Genius' of The Charing Cross, Lahore. The interesting contrast between the name i.e. Charing Cross, and the vernacular edifice 
guarding Queen's statue had very intelligently propagated and defined the authority of colonizer and the colonized on Indian land and resources. The location selected for the development of The Charing Cross, Lahore Pavilion was strategic where nobody who lived in Lahore could miss the gracious queen looking down upon the city's populace (Lahore sites of interest).

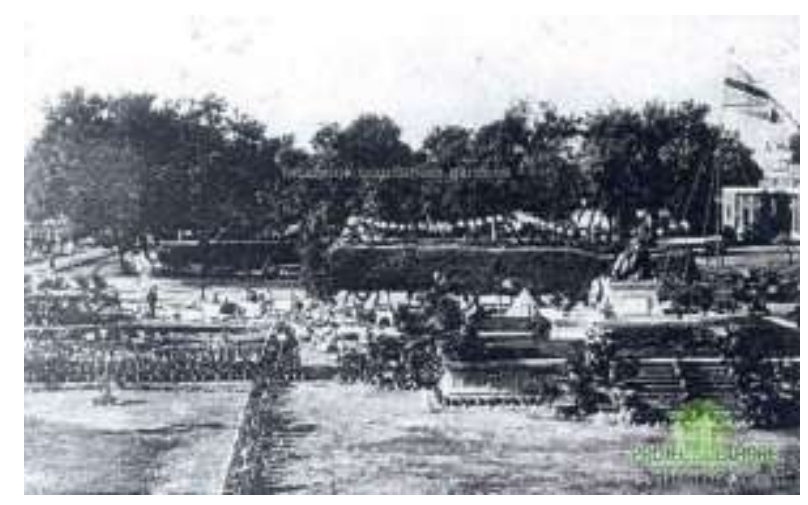

Fig. 12: Installation Ceremony of Queen Victoria's Statue - The Charing Cross, the Mall, Lahore c. 1900s ${ }^{2}$

Source: THAAP Journal 2012

Contrary to the expectation of Colonial British, The Charing Cross, Lahore turned into a hostile place for the display of their power. The social form of The Charing Cross, Lahore morphed into a politically and culturally charged space echoed by the expression of common public; local leaders and representatives rather than colonial authorities. A place dominated by the physical presence and psychological influence of British Queen was now a place where protests to overthrow her throne were being demanded. Since then The Charing Cross, Lahore has been serving as an interface between the common public and legislative authorities. The colonial era witnessed The Charing Cross, Lahore feeding on demonstration and performance. Movements and voices altering the course of Indian history had begun to take support of the spirit of The Charing Cross, Lahore.

The post independent witnessed The Charing Cross, Lahore in a new light where the Post-colonial phenomena re-crafted urban character of The Charing Cross, Lahore. In 1951 (Sajjad, 2012) replacement of Queen's bronze statue with model of Quran signified the change in the social and political sensibilities of newly born state culture. The statue placed in The Charing Cross, Lahore representing the authority of ruling British was replaced with the ruling authority of religious doctrine showcasing a shift in public inclination and representation.

\footnotetext{
${ }^{2}$ It was a garden (now stands Punjab Assembly Hall), where this statue was placed. Statue was casted in London in 1900 by B. Mackennal, just a year before the Queen`s death in 1901.
} 


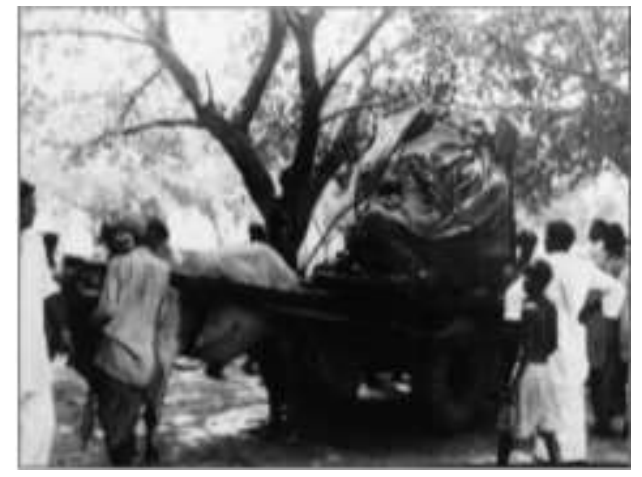

Fig. 13: Down with Statue of the Queen Source: Naz and Ashraf, 2008

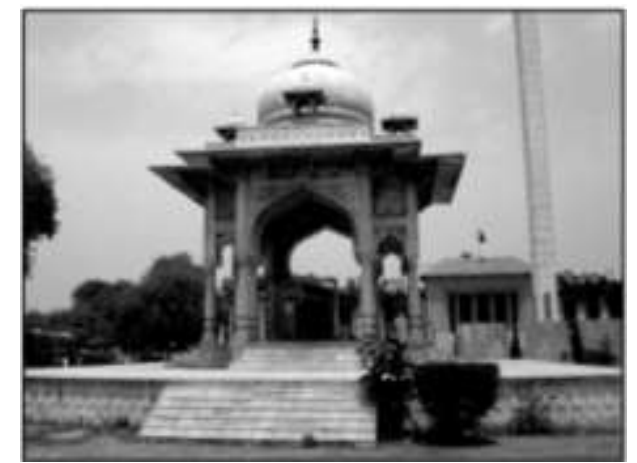

Fig. 14: British pavilion with model of the Holy Quran

Source: Naz and Ashraf, 2008

The transition of The Charing Cross, Lahore as a space into place and the development of the Genius of The Charing Cross, Lahore also dwell on experiencing the sense of the presence of those who are not physically there (Bell, 1997). The presence of Islamic Summit Minar and allied facilities, designed by Turkish architects Vedat Daloky and Ural Elhami (Naz \& Ashraf, 2008) ${ }^{3}$, commemorating the 2nd Islamic Summit Conference is the existential proof of a significant event reflecting on the physical and psychological conscious of The Charing Cross, Lahore. The 2nd Islamic Summit Conference, one of the largest gatherings of the leaders of Muslim world, was held in Lahore in 1974 during the tenure of Zulifkar Ali Bhutto. The event, where the first speaker Syrian President Hafez al- Assad was reported to announce that the representatives of the Muslims world were not meeting as makers of events rather than in reaction to events (Hasan, 1974) marked a great shift in the attitude of Muslim world and their approach towards events occurring around their world. Although The Charing Cross, Lahore was officially renamed as "Faisal Chowk" after 2nd Islamic Summit Conference, the place was and is still identified as The Charing Cross.

\footnotetext{
${ }^{3}$ Naz, N. and Zohra, A. (2008). Transformation of Urban Open Spaces of Lahore: From Charing Cross to Faisal Square. Pak. J. Engg. \& Appl. Sci, vol. 2: 65-78
} 


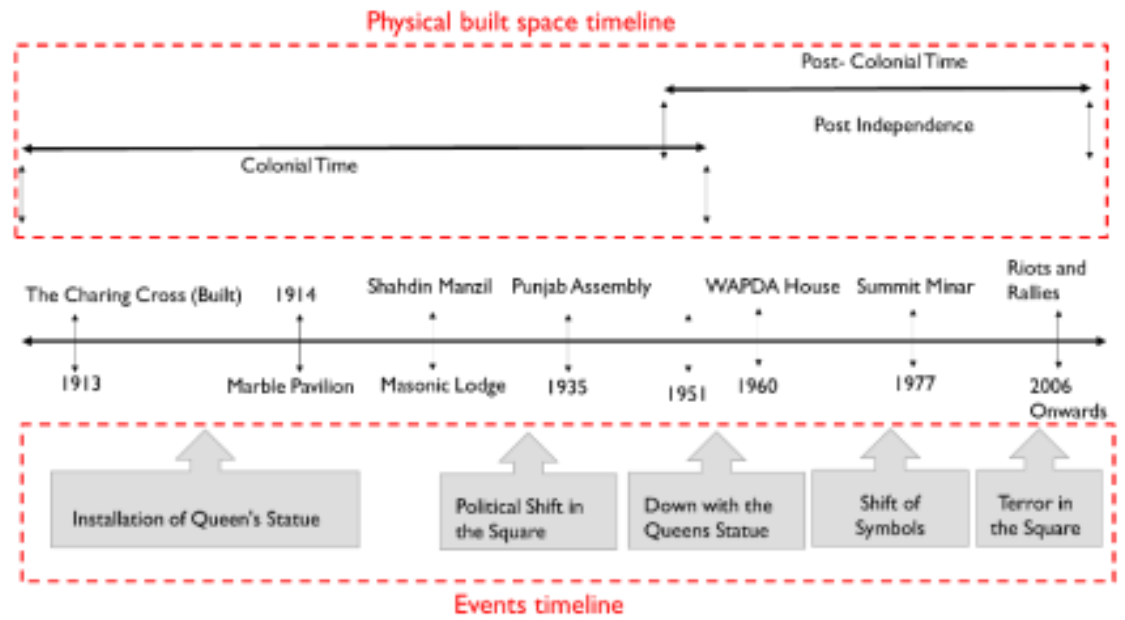

Fig. 15: Timeline of physical space and events which have contributed in making the Charing Cross a Genius Loci Source: Author

The place of The Charing Cross, Lahore in last decade, if we put it in P.C. Wren's words, was 'silent and aware'. Since 2006, The_Charing Cross, Lahore has been clouded in the smoke of riots, protests and terrorist's attacks. With this new layer of terror and politics, the genius of the place has further evolved. While the whole city has been gripped in these fears, The Charing Cross, Lahore being the center for political and administrative activities remained the main target for such events. This, in effect has had a profound impact on the physical and social fabric of the Cross. One of the immediate results of these attacks has been the blockage of public access to the Punjab assembly and the marble pavilion itself. However, this has not diminished the political value or the genius of the place as it retains the prime location for all public demonstrations, rallies and protests.

In February 2013, The Charing Cross, Lahore fell target to terrorist designs when a suicide bomber detonated his explosive vest near the Punjab Assembly as hundreds of people gathered for a protest. The Lahore blast claimed the lives of at least 14 people, including senior police officers. The protest near the Punjab Assembly was being held by chemists and owners of medical stores against the drug rules imposed by the provincial government (Geo TV, Dec 2017). 


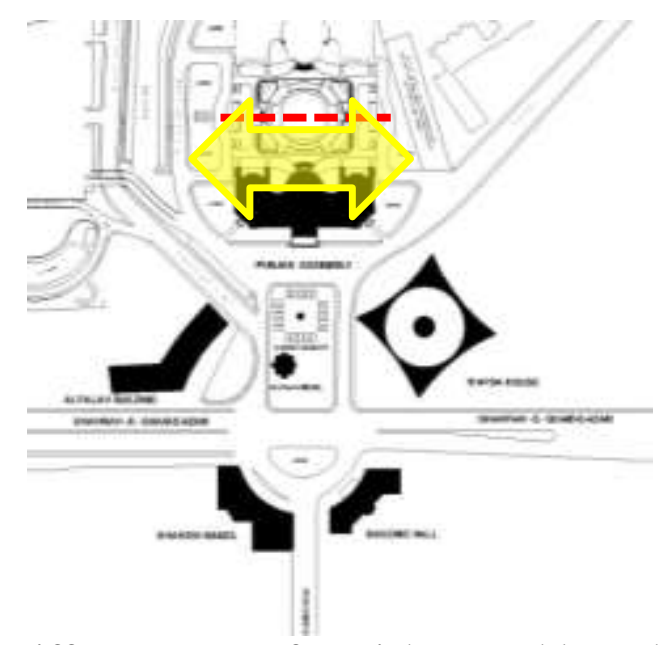

Fig. 16: Different areas of Punjab assembly and the pavilion. Source: Author and Communication \& Works Dept. Govt. of Punjab, Lahore

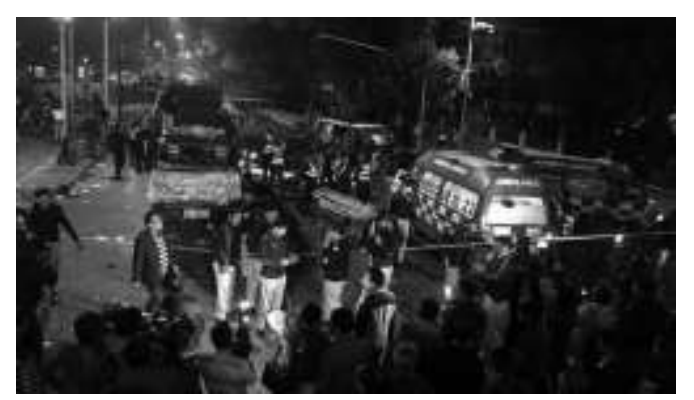

Fig. 17: After a terrorist attack in February 2013

Source: Geo News

It is important to note that The Charing Cross, Lahore is built on its identity through these, adding to the uniqueness, historic value and genius of the place within the city.

(Fig 18)

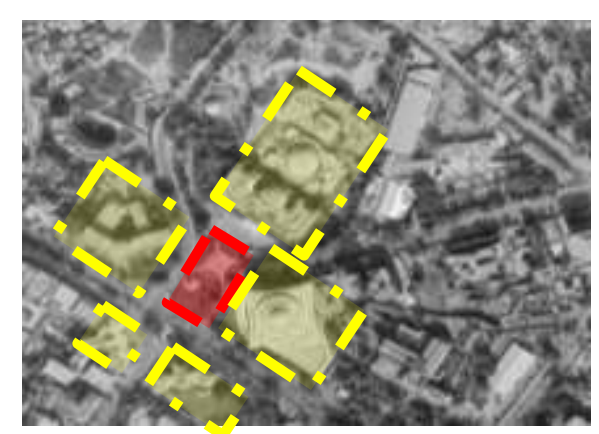

Fig. 18: The Charing Cross and its Context in 2018

Source: Author \& Google Maps 


\section{Conclusion:}

The Charing Cross, Lahore is a place representing the social, political and cultural opinion of people since centuries. From a road junction to a public square to a pavilion seldom visited, the spirit of The Charing Cross, Lahore can be experienced with the help of significant events, which has crafted its architectural narrative and timelessness. The demonstration of supremacy or the act of challenging the dominance allows The Charing Cross, Lahore to develop a Genius and to grow into a place. The spirit of The Charing Cross, Lahore since its inception has been provoking actions and reactions. The Charing Cross, Lahore has been acting as multifaceted backdrop for the events taking place in the square. The first facet in shape of Punjab Assembly faced the demonstrators as confronter. It has always played a dynamic role in maintaining the law and order situation in the city. It admits all the layers of time and irrespective of the intent of the demonstrations being staged at The Charing Cross, Lahore, the Punjab Assembly being a symbol of legislative power remains omnipresent. The two silent spectators in the square are the Shahdin Manzil and the Masonic hall, these buildings form the frame, due to their placement and location, in front of which most rallies take place. However, the internal space of The Charing Cross, Lahore and its pavilion has been subjected to constant changes in terms of its substance and use. The internal domain of The Charing Cross, Lahore at one time was accessible to the general public. Introduction of Summit Minar pushed the activity of people towards its periphery. The present form of The Charing Cross, Lahore creates a central island with heavy traffic congestion around it and the current political tension and instability of the city has further restricted the accessibility of public into the central space.

Drawing on the analysis, we can conclude that the Genius of The Charing Cross, Lahore is not a static entity; instead it has grown and developed over the years to its current stage where it is now an exhibition of multiple layers of time and events. Its Genius has experienced, absorbed and reflected impressions of multiple periods and occasions yet The Charing Cross, Lahore is able to attain an identity of its own, despite being too much for too many eras. As Schulz explained:

The structure of a place is not a fixed, eternal state. But this does not mean that the genius Loci changes or gets lost because identity can be conserved. Indeed, it has remained a living reality throughout the course of history.

Schulz, 1996;18

- It is not simply the historic form of the place but the recognition of the meaning, validity, and the richness of the place layer of significance added to the place (Kankanamge, 2016) which makes it a Genius Loci. Journey of The Charing Cross, Lahore towards unfolding of a place having a Genius is an incredible one i.e. from mere junction facilitating roads to a public square challenging dominant narrative. The spirit of The Charing Cross, Lahore has remained resolute admitting its urban transformation and social evolution. 
- The current state of The Charing Cross, Lahore is an amalgamation of Colonial urban imagination and the evolving Post-colonial experience of an urban space. Despite its official name "Faisal Chowk', the place is still identified as The "Charing Cross", Lahore and is always the first option in a rebel mind whenever any protest is planned to be staged in Lahore.

- The Charing Cross, Lahore being an urban artifact is a true Genius locus. As the square has not only witnessed but participated in several historic movements and moments that are responsible for the current physical and social culture of not only Lahore city but this region.

\section{References}

Abbas, Q. and Pir G. (2017). (De) Politicization of Public Spaces: Case of Hazoori Bagh, Data Ddarbar and Madhu Lal Hussian's Shrine. THAAP Journal: People and the City: 233-245

Brisch, N. (2012). Religion and power. Chicago: Oriental Inst. of the Univ. of Chicago. Communication \& Works Dept. Govt. of Punjab, Lahore.

Dictionary.com. (2018). Dictionary.com. Dictionary.com. https://www.dictionary.com/Accessed September 5.

Hasan, R. (1974). The Islamic Summit Conference. The Reconstruction of Religious Thought in Islam. Iqbal Academy Pakistan. April.

Marble Pavilion at Charing Cross, Lahore Sites of Interest, "Marble Pavilion at Charing Cross." sites.ualberta.ca/ rnoor/marble_pavilion.html.

Micheal, B. M. (1997). The Ghost of place. Theory and Society 26, pp. 813-836

Nayomi, H.H.K.R, and Nayomi K. (2014). Genius Loci. LinkedIn SlideShare. August 25 Norberg-Schulz, C. (1996). Genius Loci. New York: Rizzoli

Naz, N. and Zohra, A. (2008). Transformation of Urban Open Spaces of Lahore: From Charing Cross to Faisal Square. Pak. J. Engg. \& Appl. Sci, vol. 2: 65-78

Rossi, A. (2007). The architecture of the city. Cambridge, Mass: MIT Press.

Sajjad, S. F. (2012). Public Sculptures of Lahore. THAAP Journal: Portrait of Lahore: 107-124.

Terror attacks that shook Pakistan in 2017 | Pakistan - Geo.tv. (2018). https://www.geo.tv/latest/174413-terror-attacks-that-shook-pakistan-in2017Accessed September 5

TNS - The News on Sunday. (2014). The News on Sunday (TNS) » Weekly Magazine The News International. [online] Available at: http://tns.thenews.com.pk 